\title{
BENTO PRADO JUNIOR E A FILOSOFIA VIVIDA
}

\author{
Débora Cristina Morato Pinto* \\ deboramp@power.ufscar.br
}

Bento Prado Junior nos deixou em 12 de janeiro de 2007, tendo dedicado grande parte da sua vida à filosofia. Leia-se filosofia, aqui, como a reflexão constante e fina sobre temas e conceitos caros à história da filosofia em sua interface com as ciências humanas. De uma forma muito especial, o campo em que se movia ao refletir é mais fielmente circunscrito pela convergência entre a filosofia e a literatura. Sua meditação filosófica foi sempre aberta, complexa e de uma riqueza inestimável. Sua conversa filosófica, invariavelmente estabelecida ao redor de uma mesa e permeada de poesia, humor e performances artísticas, era fascinante e divertida, cativando inúmeros alunos, colegas, amigos, adversários, leigos e especialistas. Mais que isso, Bento tinha uma enorme capacidade de nos surpreender, de revelar em cada canto das obras filosóficas dimensões insuspeitadas, relações originais e recriações implícitas de conceitos dispostos no tempo lógico. Tive a oportunidade de conviver com ele a partir de três perspectivas distintas - como leitora de sua obra canônica Presença e campo transcendental; como aluna em cursos e nas avaliações de meu mestrado e meu doutorado, ambos sobre Bergson; como colega de departamento por cinco anos. Em cada uma dessas situações, tive o prazer de contar com sua generosidade, sua elegância e sua inteligência excepcional. Ressalto aqui algumas lições dessa convivência.

Ao freqüentar um curso por ele ministrado no início dos anos 1990, tomei contato com o crescente interesse de Bento - que nadara até então nas águas da fenomenologia francesa e do bergsonismo, tendo passado significativamente por Rousseau e pela psicanálise -, por um pensamento que fincava pé na

* Departamento de Filosofia e Metodologia das Ciências - Universidade Federal de São Carlos (UFSCar).

KRITERION, Belo Horizonte, nº 115, Jun/2007, p. 279-281. 
lógica: o tema do curso era "Bergson e Wittgenstein". E naquelas aulas aprendia-se como superar oposições artificialmente construídas pelo saber institucionalizado, pautadas por dissensões políticas e mesmo geográficas. Logo se descobria a fragilidade da alternativa "filosofia da linguagem X filosofia da consciência", denunciada pela ironia leve e pelo sorriso de quem olhava a má posição de um problema filosófico do alto de uma sabedoria que lhe permitia, inclusive, ter compreensão com a ingenuidade alheia. Ali também tomei contato com suas reflexões sobre um tema que ele não abandonou até o fim, a ipseidade e suas formas de expressão. Enfim, levei daquele curso para o horizonte de meu trajeto a fértil lição de que, afinal de contas, o mundo da vida e o mundo da linguagem são o mesmo. Além disso, pude usufruir de um meio acadêmico ímpar, delineado pela relação entre o mestre e os alunos e marcado pelo respeito, pelo diálogo e pela fidelidade às próprias intenções intelectuais e pessoais. Na verdade, o que ele nos dizia nas entrelinhas era isso: abraçar a filosofia só vale a pena se você puder ser fiel a si próprio. E isso a despeito do que ocorre a partir da incorporação do ideal de profissionalização aos moldes do capitalismo americano pela universidade brasileira, incluindo a valorização quantitativa, senão massificação, da produção acadêmica e o incentivo à competitividade excessiva. Ser fiel aos próprios desejos podia parecer velharia numa época tão pragmática, uma relíquia existencialista datada... Mas essa era a preciosidade adquirida, enfrentar o desafio contra a própria corrente e o espírito do tempo: assim como a gravata borboleta, os ternos com os quais ia dar aulas no calor de São Carlos, o chapéu e a bengala, marcas da sua elegância extemporânea. A fidelidade a si mesmo se expressava na sua figura e nas suas palavras.

A leitura de Presença e campo transcendental impulsionou o percurso de quase todos os pesquisadores brasileiros sobre Bergson. Aqui, levávamos vantagem: a única obra de interpretação do filósofo francês até então comparável ao livro de Bento talvez fosse o Bergsonismo de Deleuze. Sua principal contribuição consistiu em revelar aspectos essenciais, mas até então negligenciados pela literatura corrente sobre o pensamento de Bergson, através da exposição detalhada e sagaz do vínculo intrínseco entre crítica do negativo e ontologia da presença. Ao tomar essa ligação como fio condutor de sua leitura, posicionou-se contra uma interpretação realista estrita da noção de duração e desautorizou as polêmicas superficiais sobre o espiritualismo de Bergson. Através de uma escrita segura e muito elegante, que faz jus a um filósofo a quem foi concedido o Nobel de literatura, Bento nos conduz a percorrer as três obras bergsonianas capitais a partir do estudo das ilusões da razão denunciadas no último capítulo de $A$ evolução criadora. Ao tomar 
como alicerce dessa leitura a noção de campo transcendental, estabelece uma análise de enorme relevância para a recuperação do sentido mais essencial da filosofia de Bergson, assim como para bem determinar sua inserção no debate contemporâneo, que se explicita no espaço de convergência e confronto com a tradição fenomenológica. Se, em larga medida, o livro deu a tônica do contexto filosófico em que o estudo de Bergson se moveria no Brasil, marcado pela ênfase na análise dos "aspectos transcendentais" da filosofia da duração, sua publicação na França inverteu o sentido mais comum do diálogo franco-brasileiro: imediatamente após sua tradução, passou a ser obrigatória e sistematicamente citado em artigos e debates franceses em torno de Matéria e Memória e das relações entre a intuição bergsoniana e a fenomenologia. Lamentem-se apenas os longos intervalos entre sua redação (1964), sua publicação no Brasil (1989) e sua posterior tradução e publicação na França (2002), esta última em consequiência de um acaso biográfico que permitiu a um renomado fenomenólogo poder compreender o alcance e o rigor das análises de Bento, bem como a sua admirável escrita - Renaud Barbaras, o tradutor do livro para o francês, falava perfeitamente a nossa língua e era freqüente consumidor da boa literatura brasileira. A história de Presença e campo transcendental, aliás, ilustra, por si só, as agruras de escrever sobre filosofia em português, língua marginal no debate acadêmico mundial.

Mas foi nos últimos anos que pude observar de perto a atuação de Bento no Programa de Pós-Graduação em Filosofia da UFSCar, acompanhando-o nas diversas atividades cotidianas do fazer filosófico no ambiente universitário. E só então pude compreender de fato a densidade de sua presença. Aliando uma invejável capacidade de trabalho ao amor pela boemia, o professor propiciava aos colegas, funcionários e alunos uma convivência alegre e um aprendizado constante. A defesa da fidelidade a si e da liberdade era praticada nas orientações de teses e nas deliberações dos procedimentos e regras institucionais; a profundidade de sua reflexão era compartilhada através da docência que fascinava os alunos e atraía ouvintes de todos os tipos; o convívio social e afetivo sempre em torno da filosofia funcionava como tempero e alento em meio às dificuldades da pesquisa e do exercício da reflexão no contexto da universidade brasileira. Poder trabalhar com filosofia e ouvir Bento cantando ópera, imitando artistas de cinema, recitando a Divina Comédia de cor em italiano, emocionando-se com as canções de Chico Buarque, contando histórias deliciosas do passado e do presente, enfim, celebrando a vida e a arte, a poesia e a filosofia, foi um enorme privilégio. Por isso mesmo, sua morte ensina o que pode ser o peso de uma ausência e nos deixa a imensa responsabilidade de zelar por seu legado. 